4. Верхарн Э. Толпа / пер. М. Волошина // Э. Верхарн. Стихотворения. Зори. М. Метерлинк. Пьесы. БВЛ. М.: Художественная литература, 1972. С. 157-160.

5. Дзадзиев А .Б, Дзуцев Х. В, Караев С. М. Этнография и мифология осетин. Краткий словарь. Владикавказ: Издательско-полиграфическое предприятие В. А. Гассиева, 1994. 284 с.

6. Джикаев Ш. Ф. Осетинская литература. Краткий очерк. Орджоникидзе: Издательство СОГУ, 1980. $112 \mathrm{c}$.

7. Долгополов Л. К. На рубеже веков. О русской литературе конца XIX- начала XX века. Л.: Советский писатель, 1977. 368 с.

8. Колобаева Л. Н. Русский символизм. М.: Изд-во Московского университета, 2017. 352 с.

9. Копелев Л. Драматургия немецкого экспрессионизма // Экспрессионизм. Сборник статей. М.: Издательство Наука, 1966. С. 36-83.

10. Кравчук О. С. Внутренний пейзаж в раннем романном творчестве Гайто Газданова // Вестник Северо-Осетинского государственного университета им. К. Л. Хетагурова. Общественные науки, 2013. №4. С. 273-277.

11. Ласица Е. В. «Пейзаж души» в сборник П. Верлена «Добрая песня»// Вестник полоцкого государственного университета. Серия А. Гуманитарные науки. 2015. №2. С. 37-41.

12. Литературный энциклопедический словарь / Под общ. ред. В. М. Кожевникова и др., М.: Советская энциклопедия, 1987. 752 с.

13. Литературная энциклопедия терминов и понятий / Под ред. А. Н. Николюкина. М.: НПК «Интелвак», 2001. $1600 \mathrm{c.}$

14. Лотман Ю. М. О поэтах и поэзии. СПб. : Искусство, 1999. 848 с.

15. Нольде Э. Об искусстве и своем творчестве. Заметки на полях / пер.с нем. Ю. Маркина // Творчество. 1991. №2. с.9-11.

16. Пестова Н. В. Лирика немецкого экспрессионизма. профили чужести. Екатеринбург: Издательство Уральского педагогического университета, 2010. 463 с.

17. Терехина В. Н. Экспрессионизм в русской литературе первой трети XX века: Генезис. историкокультурный контекст. Поэтика. М.: ИМЛИ им. А. М. Горького РАН, 2009. 320 с.

18. Токаты А. Уацмыстæ. Орджоникидзе: Ир, 1973. 308 ф.

19. Тракль Г. Стихотворения. Проза. Письма. СПб.: Symposium, 1996. 640 с.

20. Тресиддер Дж. Словарь символов / пер. с англ. С. Палько. М.: ФАИР-ПРЕСС, 1999. 448 с.

21. Хетагуров Д. Б. Нагорный луг (стихи на осетинском языке). Орджоникидзе: Северо-Осетинское книжное издательство, 1961. 152 с.

22. Хёг П. Дети смотрителей слонов: Роман. Перевод с дат. Е. В. Красновой. СПб.: «Симпозиум», 2012. $416 \mathrm{c.}$

23. Элиаде М. Избранные произведения. Очерки сравнительного религиоведения / пер с англ. Ш .А. Богиной и др., М.: Ладомир, 1999. 488 с.

24. Эпштейн, М. Н. «Природа, мир, тайник вселенной...»: Система пейзажных образов в русской поэзии. М.: Высшая школа, 1990. 303 с.

\title{
Zorina Yu.V. \\ Experience in describing semantic categorical structure of terminology
}

Omsk State Technical University (Russia, Omsk)

doi: $10.18411 / \mathrm{lj}-10-2019-225$

idsp: ljournal-10-2019-225

\section{Аннотация}

В статье представлен опыт описания семантической категоризации английской терминологии научно-технической области безопасности жизнедеятельности. Данный семантический процесс базируется на осмыслении системных отношений между терминами указанной специальности. В этой связи терминологический набор организуется в макрокатегории, базовые категории и дифференциально-семантические группы.

Ключевые слова: термин, терминология, категоризация, макрокатегория, базовая категория, дифференциально-семантическая группа

\section{Abstract}

The experience of describing semantic categorization of the English terminology of the scientific and technical field of public safety is presented. This semantic process is based 
on the understanding of the system relations between the terms of the specified specialty. In this regard, the terminological set is organized into macro categories, basic categories, and differential-semantic groups.

Keywords: term, terminology, categorization, macro category, basic category, differential-semantic group

Scientists identify the categorization of the world as a key cognitive process, taking into account an active role in the cognition of the world and considering cognitive activity as a set of processes of perception, thinking, memorizing, aimed at the evolution of the world.

Categorization is a classification process aimed at "combining similar or identical units into larger categories" [1, p. 96]. While processing incoming information, a person divides the world and allocates classes, groups, categories and identifies objects, mentally correlating the object with a certain category. Categorization in the language is found in the existence of various semantic classes of words (semantic fields, thematic groups, lexicosemantic groups, etc.) [2, p. 17].

One of the well-known cognitologists investigating the concept of categorization, J. J. Lakoff believes that it underlies all human thought processes: "If we did not have the ability to categorize, we would not be able to act at all, either in the physical world or in our social or intellectual life. Understanding of the way we categorize is essential to understanding how we think and how we act, and therefore essential to understanding what makes us human beings" [3, p. 20]. Categorization occurs unconsciously, and a person thinks about its existence only in problem situations [2, p. 45].

Choosing a particular language means, the speaker offers a certain way of understanding the subject or event and relies on the collective experience of categorization of the world in language, which is reflected in language knowledge. Any knowledge perceived by a person is the result of categorization of the surrounding world [4, p. 39]. In the system of language categorization peculiarities of language knowledge are presented in three types of categories: lexical, grammatical, modus.

The lexical category formation is based on invariant-variant logical principle. This means that the center of the category becomes the word with the most general meaning, which simultaneously serves as the name of the category, its invariant, and the main identifier in relation to other elements of this category are words with a specific meaning that is its variants [4, p. 42].

On the basis of the invariant-variant principle, various semantic classifications of vocabulary, presented in lexicographic parameters in ideographic dictionaries, are constructed.

In the process of work on the distribution of language material by semantic classes, we focused on the "Dictionary-thesaurus of synonyms of Russian speech" edited by L. G. Babenko [5]. Semantic categorization of the scientific terminological field of PUBLIC SAFETY in English language is based on the experience of categorization of the world in the form of a list of categories on different levels (macro categories, basic categories, differential semantic groups), which were developed taking into account their hierarchy [6, p. 7]. There is no field of knowledge which could be studied and developed without having mastering its terminology. Permanent encouraging professional competence of a specialist requires certain terminological knowledge, which contributes to the further development of human intellectual abilities [7, p. 21].

Hierarchy of the specified categories is reflected in the following division: at the first level of hierarchy there are three groups representing macro categories:

HAZARDS

PERSON

PROVIDING SECURITY 
These macro categories are divided into differential semantic groups (DSGs), which are further concretized in different ways.

The most detailed classification can be represented for the macro category HAZARDS. The notion of hazard, danger is the central concept of the scientific and technical field of life safety, which refers to any phenomena that threaten human life and health. This term is the center of the macro category, at the same time its name. Further, the macro category "HAZARDS" is divided into seven basic categories (BCs):

1.1. general concepts

1.2. social dangers

1.3. natural hazards

1.4. biological hazards

1.5. anthropogenic hazards

1.6. environmental hazards

1.7. consequences of being exposed to hazards

The first basic category "general concepts" includes 9 terms with a common semantic component unexpected event: accident, failure, hazard.

The second basic category is the category "social hazards". It describes those that are widespread in society and threaten the life and health of people. Carriers of such dangers are people belonging to certain social groups. It includes two DSGs.

DSG 1.2.1. "general concepts" is represented by 5 terms: cacoethes, consumption, habit

DSG 1.2.2. "types of social hazards" is represented by 43 terms: abuse, alcoholism, assault, blackmail, kidnapping, rape, speeding, suicide, terrorism, unemployment, warfare

The third basic category "natural hazards" includes notions corresponding to natural phenomena that directly threaten the life and health of people. The category consists of six DSGs.

DSG 1.3.1. "general concepts" is represented by 7 terms: calamity, convultion, disaster

DSG 1.3.2. "lithospheric hazards" has 15 terms with the general meaning of "natural phenomena of geophysical origin": earthquake, earthslide, volcano eruption, rockfall, avalanche

DSG 1.3.3. "hydrospheric hazards" has 11 terms: flood, freshet, tsunami, overflowing, waterquake

DSG 1.3.4. "atmospheric hazards" is represented by 38 terms: anticyclone, cyclone, drought, fireflaught, fog, blizzard, freeze, hurricane, lightning, tornado

DSG 1.3.5. "space hazards" is represented by 2 terms: asteroid, insulation

DSG 1.3.6. "characteristics of natural phenomena" has 24 terms: magnitude, focus

The fourth basic category "biological hazards" denotes those ones that are caused by living organisms. The category includes seven DSGs.

DSG 1.4.1. "general concepts" is represented by 20 terms: aerobe, carnivore, fungus

DSG 1.4.2. "microorganisms" has 9 terms: microbe, rickettsia, bacillus, staphylococcus, spirochete, titer

DSG 1.4.3. "viruses" has 4 terms: filter-passer, pneumovirus, virus, viron

DSG 1.4.4. "mushrooms" has 3 terms: actinomycete, phytophthora, toadstool

DSG 1.4.5. "plants" is represented by 36 terms: antiar, datura, strychnine, azalea, bay tree, elderberry, oleander, upas, strychnine

DSG 1.4.6. "animals" is represented by 26 terms: acarid, mamba, shark, bee, jellyfish, mite, viper, wasp

DSG 1.4.7. "harmful organs" has 4 terms: fang, gland, sting, stinger

The fifth basic category "anthropogenic hazards" denotes those ones that arise in the course of functioning of technical objects for the reasons which are not directly connected with activity of the person serving these objects. These are the hazards connected directly 
with the nature of mechanisms, machines, constructions, technical devices. The category includes five DSGs.

DSG 1.5.1. "general concepts" is represented by 14 terms: wrecking, vapour, mishandling-non

DSG 1.5.2. "mechanical hazards" has 22 terms: abrasion, overturn, vibration, noise, ultrasound, firing, rigidity, yielding

DSG 1.5.3. "physical hazards" has 11 terms: static electricity, ionization, radiation, current, electromagnetic field, emission

DSG 1.5.4. "chemical hazards" is divided into 5 subgroups:

1.5.4.1. "general concepts" has 15 terms: acid, hallucinogen, aerosol, agent, flame, amide, solution, perchlorate

1.5.4.2. "solids" has 54 terms: arsenic, silica, zinc

1.5.4.3. "liquids" has 4 terms: acetone, acrolein, acrylonitrile

1.5.4.4. "gases" has 7 termss: ammonium, chlorine, nitrogen

1.5.4.5. "chemical processes" is represented by 1 term: flaming

DSG 1.5.5. "psychophysiological hazards" has 1 term: physical overwork

DSG 1.5.6. "environmental hazards" is represented by 19 terms: xenobiotic, warming, pesticide, wastewater, fallout, radio-contamination

DSG 1.5.7. "consequences of being exposed to hazards" is represented by 26 terms: wreckage, gray-out, lesion, injury, impairment, hurt

The second macrocategory "PERSON" is divided into three basic categories:

2.1. status of a person

2.2. characteristics of a living organism

2.3. pathological condition of a living organism

The first basic category 2.1. "the status of a person" includes two DSGs.

DSG 2.1.1. "victim" is represented by 16 terms: abductor, escapee, wounded, addict, drinker, incapacitated, pilferer, poisoner, speeder, survivor

DSG 2.1.2. "rescuer" has 32 terms: aidman, firefighter, rescuer, assurer, firefighter, inspector, lifeguard, ratcatcher

The second basic category 2.2 "characteristics of a living organism" has 28 terms: vigilance, magnification, accumulation, well-being, immunity, fragility, acommodation, abstinence

The third basic category 2.3 "pathological state of a living organism" has 190 term units: zymosis, lassitude, haemorrhage, wasting, perturbation, panic, lassitude, inanition, leprosy

The third macro category "PROVIDING SECURITY" is divided into three basic categories:

BC 3.1. "method of protection" has 166 terms: warning, isolation, disinfection, injection, restitution, purification, quarantine, recovery, zoning

BC 3.2. "means of protection" has 143 terms: respirator, fire-hook, antibiotic, waterbreak, zoocide, speed-trap, lifeline, glasses, shield

BC 3.3. "characteristics of matter, substance" has 22 terms: toxicity, instability, fireresistance, severity, humidity, filterability, instability

As can be seen from the list of semantic categories, it is no coincidence that it is the category "HAZARDS" is so complex in terms of structure. In the aspect of cognition of reality, it is important for a person cognizing the reality to identify the causes that threaten his life and economic activity. This shows the anthropocentrism of the terminological system "PUBLIC SAFETY" in English, and therefore the group of "HAZARDS" is easily classified by types of hazards. Semantic classification in this group is based on the denotative principle, in which each semantic class corresponds to a class of objects of the real world.

Macrocategories "PERSON" and "PROVIDING SECURITY" are defined on the basis of the semantic principle. In the category "PERSON" there are the names of people by status 
in this area: "victim" and "rescuer". In the category "PROVIDING SECURITY" terms are classified depending on the categorical semantics of word classes ("method, method of protection", "means of protection", "property, quality, sign of matter, substance").

So, in the proposed classification, two principles are combined: denotative (for the category of "HAZARDS") and semantic (for the categories of "PERSON", "PROVIDING SECURITY").

Summing up it should be noted that the scientific terminological field of PUBLIC SAFETY in English language presented in the system of macrocategories, basic categories and differential semantic groups of words displays fragments of reality associated with the existence of various hazards affecting a person, and a person's struggle with these hazards.

$$
* * *
$$

1. Kubryakova E.S. Chasti rechi s cognitivnoyi tochki zreniya. M. : Izd-vo Ins-ta yazykoznaniya RAN, 1997, $327 \mathrm{~s}$.

2. Plotnikova A.M. Cognitivnaya semantika : ucheb. posobiye / A.M. Plotnikova. - Yekaterinburg: Izd-vo Ural. Un-ta, 2008. - $160 \mathrm{~s}$.

3. Lakoff J. Women, Fire, and Dangerous Things: What Categories Reveal About the Mind University of Chicago Press. M.: Yazyki slavyanskoy kultury, 2004. - 792 s.

4. Boldyrev N.N Cognitivnye issledovaniya yazyka. Vyp. IV. Contseptualizatsya mira v yazyke : kollectiv. monogr. - M.: Ins-ta yazykoznaniya RAN; Tambov : Izdatelskiyi dom TGU im. G.R. Derzhavina, 2009. $-460 \mathrm{~s}$.

5. Slovar-tezaurus sinonimov russkoy rechi / pod red. L.G. Babenko. - M.: AST-PRESS KNIGA, 2008. $512 \mathrm{~s}$.

6. Kontseptosfera russkogo yazyka : klyuchevye kontsepty i ih reprezentatsii (na materiale leksiki, frazeologii i paremiologii): prospekt slovarya / pod obshch. red. prof. L.G. Babenko. - Yekaterinburg: Izd-vo Ural. Un-ta, 2010. - $340 \mathrm{~s}$.

7. Zorina Yu. V. Obuchenie terminologii - put k professionalnoi kompetentsii. M. Fundamentalnye issledovaniya, 2007, №3, 21 s. 